Article

Trade Misreporting: A Case of Zimbabwe Journal of Development Economics and Foreign Trade Management Research Studies (JDMS), A Peer Reviewed Open Access International Journal

ISSN: 25825119 (Online)

06(06), 1-16, October-December, 2020

@ Center for Development Economic

Studies (CDES)

Reprints and permissions

http://www.cdes.org.in/

http://www.cdes.org.in/journal/

\title{
Trade Misreporting: A Case of Zimbabwe Foreign Trade
}

\author{
MBUDZI CRYLOW \\ Faculty of Social Studies and Economics Department \\ University of Zimbabwe \\ 202 Robert Mugabe, Harare, \\ Zimbabwe
}

\begin{abstract}
Theoretically it is presumed that Zimbabwe's exports to Malawi should be the same as Malawi's imports from Zimbabwe. However, if we look at the data reported by the two countries, we find shocking dispersion. In principle, the two reported trade values should differ systematically only by transport costs, because the values reported by importers include freight and insurance. These double reports provide an opportunity for audit. This paper presents a methodology to measure misreported trade in a consistent way across countries and over time. The methodology does not require any assumptions about which countries may be more or less likely to misreport - rather, all indices are derived endogenously with available trade data. This study derived two specific indices which are exports and imports misreporting. Applying this method to existing bilateral trade data on the SITC $0+1+22+4$ level from 2000-2016, the study was able to determine factors which causes misreported trade for Zimbabwe's bilateral trade using Feasible Generalized Least Squares (FGLS) method. As predicted by economic theory, case studies, and economic intuition, the study find a significant correlation for tariff, corruption, gross domestic product rates and foreign direct investment with import and export misreporting. The study recommend reduction of misreporting after the application of policy to reduce tariff rates, implementation of the policy of increasing the maximum financial penalties and switching from exports of raw materials and semi-manufactured goods to high valued-added goods.
\end{abstract}




\section{Introduction}

A typical and frequent feature of many fraudulent acts is the misdeclaration of economic activities (Silverstone et-al., 2004). Income and earnings from illegal businesses, for example, commonly remain unreported to fiscal authorities in order to hide such operations. Expenditures eligible for public fund reimbursement, in contrast may be overstated to increase transfer revenues (Silverstone et-al., ibid). In general, publicly recorded activities may be misreported for a broad range of potential reasons.

Declarations of cross-border trade transactions are not exempt from such misconduct. According to Panayi (2015), the developing internationalization of the trade can be misused in numerous ways with one of them being income shifting so as to avoid tax or tariffs mispricing in order to get subsidies and several others. The trade data for country A for its exports to country B is expected to match the imports from country A. However, in mirror data for international trade one often finds huge deviation. In false reporting, criminal traders face incentives to fake data entries in customs declarations and other official documents for various reasons and along almost every dimension (Nitch, 2017). For instance, the quantity and the value of a shipment may be manipulated to either reduce the payment of customs duties (under-reporting or to better take advantage of export subsidies (over reporting); a misclassification of products or a misdeclaration of the ultimate destination of a shipment may allow circumventing trade restrictions (Nitch, ibid). Overall, the accuracy of international trade statistics is likely to be compromised, to an unknown degree, by fake transactions.

Dalu et al. (2012), asserted that the greatest problems facing the government of Zimbabwe is the problem of tax evasion and tax avoidance. A country facing an increasing amount of tax evasion, tax avoidance and capital flight is likely to exhibit a low productive investment mix, this would mean low economic growth and the public run enterprises would be negatively affected. Hence, it can be noted that these 'devils' have created a great gulf between actual and potential revenue. The Zimbabwe Revenue Authority (ZIMRA) have for a considerable time been complaining of the widespread incidence of tax avoidance and evasion in the country as companies and importers employ various tax avoidance strategies to escape or minimise their taxes or deliberately employ fraudulent ways and means of evading tax altogether sometimes with the active collusion of the tax officials (Dube, 2014). It can also be noted that misreporting of trade brings with it a lot of economic challenges, for instance tax avoidance causes investment distortions and thus companies and individuals would undervalue or even have some of their assets exempted from tax purposes. Whereas tax evasion on the other side would cause distortions in revenue collected. Hence this would negatively affect the economy in that, there would be inflationary pressures as recorded between 2007-2008 whereby there was an increased volume of cash and this would lead to large amounts of cash chasing too few goods hence inflation sky rockets. It is therefore of paramount importance that ZIMRA and the government work hand in hand to curb the problem.

\section{Literature Review}

Misreporting plays a big role in terms of illegal goods transactions in the world. The Global Financial Integrity's (GFI) 2013 by Kar and Spanjers (2015) report calculate that developing countries averagely lose $\$ 542$ billion dollars annually over the past 10 years due to illegal trade. Some 80 percent of that value occurs because of misreporting. The 
government cannot receive income from the transaction. African countries lost between $\$ 597$ billion to $\$ 1.4$ trillion out of the continent (1980-2009). In reality, fabricated trade statistics can put policymakers in difficult situations, since trade data play a central role in macroeconomic policymaking, as well as in trade and foreign policy considerations. Examples include public policies related to protectionist tariff measures, trade negotiations, capital controls, or export support programs. Trade data might also substantially influence countries' internal democratic decision making processes.

According to Buehn-Eichler (2010) and Nitsch (2009), misreporting was created for economic motives. As an illustration, if the imported goods entering a country are not recorded, then the entrepreneur (exporter) may gain advantage from the black market, because it is eluded from taxes and import duties. Farzanegan (2009), and Buehn-Eichler (2010), in their studies concluded that fine sanctions negatively affect smuggling activities which is indicated by misreporting. Fisman et al. (2008) found that smuggling is closely related to corruption in a country. They analyze smuggling relationships with corruption in the trade in antiques and cultural art objects. Murphy (2011) and Suryanto (2016) used the Control of Corruption index as the dependent variable to analyze misreporting. Murphy explicitly proposed the hypothesis that there is a significant relationship between the level of corruption of a country and the difference in the listing of exports. Murphy's (2011) suggests that trade openness is significant against misreporting. Same result has been made from a research conducted by Buehn-Eichler (2010), which states that the trade openness has a significant positive effect on import-misreporting. However, these studies usually have to rely on the assumption that countries commonly labelled as developed report their bilateral trade data correctly, whereas developing countries do not.

For developing nations like Zimbabwe has adverse welfare and distributional consequences hence increasing income inequality and jeopardising employment prospects. According to a misreporting index constructed by Farhad et al. (2018), Zimbabwe was ranked in the top ten countries known for misreporting trade. In so far as the effects of misreporting trade in Zimbabwe continue to be an impediment to robust and long-run economic growth, it is necessary to investigate the factors which contribute to misreporting of trade in Zimbabwe with a view of enriching the existing empirical studies on the issue. In addition, the vast majority of the associated studies focus on individual country pairs or a small group of selected trading partners to investigate trade misreporting. This research is confined to Zimbabwe bilateral trade data paying special attention to food products imports and exports since food products are ranked in the top ten imports and exports ${ }^{1}$ of Zimbabwe. The main focus of the study is to determine factors which drive misreporting of trade for Zimbabwe and trading partners.

\section{METHODOLOGY}

\section{Research Objectives}

- Determine the relative contribution of various factors to the problem of exports and imports misreporting in Zimbabwe.

- Evaluate whether exports and imports misreporting motivated by tariff evasion could be a global phenomenon or whether this phenomenon remains unique for Zimbabwe bilateral trade relationships.

\footnotetext{
${ }^{1}$ This was taken from the data published on Zimbabwe Investment Authority (ZIA) (2018), website
} 


\section{Empirical model specification}

Explained below are the two empirical models of misreported trade used in this study following Farhad et al. (2018). Necessary adjustments were made through dropping and addition of some variables based on theoretical and empirical justifications for the model to suit the Zimbabwean situations. The two models are exports and imports misreported model discussed one after the other.

\section{Export Misreporting Model}

$M R I_{i t}^{x}=\beta_{0}+\beta_{1}$ tar $_{i t}+\beta_{2}$ topen $_{i t}+\beta_{3} f d i_{i t}+\beta_{4} g d p c_{i t}+\beta_{5} c p i_{i t}+\mu_{i t}$

From equation 3.3 the notations are defined as follows:

$M R I_{i t}^{x}$ is the export misreporting index, tar $_{i t}$ is the tariff, topen $n_{i t}$ is trade openness, $f d i_{i t}$ is net foreign direct investment inflows as a percentage of GDP, $g d p c_{i t}$ is GDP per capita, $c p i_{i t}$ is the corruption perception index and $\mu_{i t}$ is the error term. The subscript $i$ represents country $i$ whilst $t$ represents time in all the variables.

\section{Import Misreporting Model}

$$
M R I_{i t}^{m}=\beta_{0}+\beta_{1} \text { tar }_{i t}+\beta_{2} \text { topen }_{i t}+\beta_{3} f d i_{i t}+\beta_{4} g d p c_{i t}+\beta_{5} c p i_{i t}+\mu_{i t}
$$

From equation 3.2 the notations are defined as follows:

$M R I_{i t}^{m}$ is the import misreporting index, tar $_{i t}$ is the tariff, topen tit $_{\text {it }}$ trade openness, $f d i_{i t}$ is net foreign direct investment inflows as a percentage of GDP, $g d p c_{i t}$ is GDP per capita, $c p i_{i t}$ is the corruption perception index and $\mu_{i t}$ is the error term. The subscript $i$ represents country $i$ whilst $t$ represents time in all the variables.

\section{MRI $I_{i t}^{\mathrm{X}}$ Is the Export Misreporting Index and MRI $I_{\text {it }}^{\mathrm{X}}$ Is the Import Misreporting Index}

In equation 3.1 and 3.2, MRI $\mathrm{I}_{\mathrm{it}}^{\mathrm{x}}$ is the export misreporting index and $\mathrm{MRI}_{\mathrm{it}}^{\mathrm{M}}$ is the import misreporting index were used as the dependent variables, to assess the factors which determine misreported trade. The indices were computed using data from World Bank Data base closely following Farhad et al. (2018) procedure. The indices were computed as follows

\section{Theoretical Framework}

The nature of reported trade data provides us with a straightforward way to identify the existence of misreporting. Nevertheless, assigning discrepancies to one of the trading partners is challenging since differences may be induced by either or both parties involved. Let us assume that, in a given year, Zimbabwe reports exporting US\$100,000 worth of food product to its trading partner say South Africa. However, the trading partner (South Africa) reports only US\$50,000 worth of food products imports. It is, therefore, difficult to determine who is misreporting.

\section{STEP 1: Deriving Weighted Trade Values}

The first step was to derive a comparable index of trade misreporting consists in identifying the degree to which a given country misreports its exports and imports in a given year. These numbers were used to calculate the weighted value for each bilateral trade 
transaction. The study began by considering the 'reporting distance' of all bilateral trade reported by a country and all of its trading partners.

\section{Export Weighting Factors}

The first step consists in using the absolute reporting distance of Zimbabwe's reported export values with the respective importer-reported imports values. Unreported trade values were considered as zeros where one party reports non-zero trade, whereas corresponding partner reports nothing. From the above example of Zimbabwe the absolute reporting distance is US\$50,000. Therefore, the export weighting factor (EWF) for Zimbabwe in this example is one minus the ratio of the total absolute reporting distance divided by the sum of Zimbabwe's reported exports and its trading partner' recorded imports. In the above scenario we get $1-\frac{50,000}{100,000+50,000}=0.667$. Naturally, the closer the EWF comes to zero, the less misreporting we observe. From this example the study formalised the derivation of the EWF. Considering total reported food products exports from all the five major trading partners ${ }^{2}(\mathrm{~S})$ to all destination countries (D) as $\mathrm{X}_{\mathrm{SD}}$ and total reported food imports by importing destination countries from each importing $\mathrm{M}_{\mathrm{Ds}}$.

The absolute reporting distance $\delta_{s D}$ for Zimbabwe reported food products export values from its counterparts reported import values was calculated as

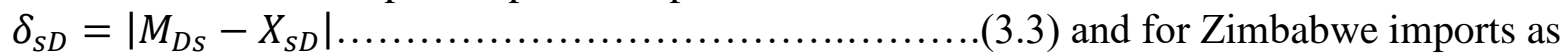

$\delta_{d S}=\left|X_{d S}-M_{S d}\right|$

\section{Export and Import Weighting Factors}

The export weighing factor $w_{s}^{x}$ (EWF) was derived as one minus the ratio between the absolute reporting distance and the sum of a country's reported exports and the total imports of counterparts as:

$$
w_{s}^{x}=1-\frac{\delta_{s D}}{X_{S D}+M_{D s}}
$$

Formally, the import weighing factor $w_{S}^{m}$ (IWF) was derived analogously to equation 3 with:

$$
w_{d}^{m}=1-\frac{\delta_{d S}}{X_{d S}+M_{S d}} \text {. }
$$

\section{Calculating Weighted Trade Values}

The EWF and IWF values provide proxies for reliability levels with which each country reports its exports and imports, based entirely on reported data as opposed to ad-hoc assumptions about the reliability of one country's data over another Farhad et al. (2018). With this the weighted trade values were computed for each trade entry.

The weighted exports value for food products from source country $s$ to destination country $D$ was calculated as

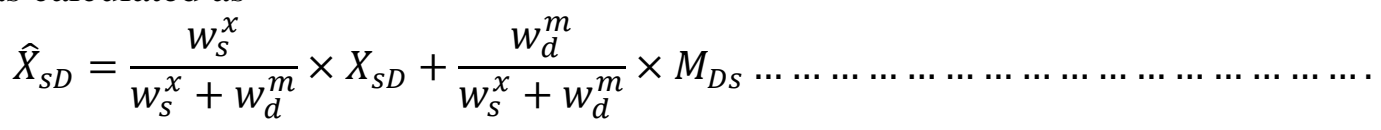

\footnotetext{
${ }^{2}$ South Africa, Botswana, Mozambique, Malawi and Zambia (According to World Bank 2016 these countries are the top partner countries to which Zimbabwe Exports and Imports Food Products)
} 
The corresponding predicted import value $\widehat{M}_{d s}$ for each reported import product, using the importing country's IWF and the corresponding country's EWF we obtain

$$
\widehat{M}_{d s}=\frac{w_{d}^{m}}{w_{s}^{x}+w_{d}^{m}} \times M_{d S}+\frac{w_{d}^{m}}{w_{s}^{x}+w_{d}^{m}} \times X_{S d}
$$

\section{Step 2: Construction of Trade Misreporting Index}

With the derivation above the misreporting indices were constructed.

\section{Export Misreporting Indices}

First, the misreported export value $\tilde{X}_{S D}$ for the food products was calculated as the difference between the reported value $\left(X_{S D}\right)$ and the weighted value $\left(\hat{X}_{S D}\right)$

$$
\tilde{X}_{S D}=X_{S D}-\hat{X}_{S D}
$$

According to Farhad et al. (2018), this step is perhaps best comparable to a so-called Contest Success Function. Formally, we label the overall export misreporting index for source country $s$ as

$$
M R I_{s}^{x}=\frac{\tilde{X}_{s}}{\tilde{X}_{s}+X_{s}} .
$$

\section{Import Misreporting Indices}

The corresponding indices for import misreporting follow analogously and it is sketched briefly here. The misreported import values as:

$$
\widetilde{M}_{d s}=M_{d s}-\widehat{M}_{d s}
$$

Next the overall import misreporting index was calculated as:

$$
M R I_{d}^{m}=\frac{\widetilde{M}_{d}}{\widetilde{M}_{d}+M_{d}}
$$

\section{Data Sources, Type and Period}

The study used annual panel data of Zimbabwe and its five major African trading partners for the period 2000 to 2016. The dependent variable used in the analysis was exports misreporting indices and imports misreporting indices. The indices were generated from annual data collected from World Integrated Trade Solutions (WITS) data base and annual average tariffs on food imports was also obtained from WITS database. Data on GDP per capita in US dollars, inflation, net foreign direct investment inflows and trade openness were from the International Monetary Fund (IMF) and World Economic Outlook database. Data on corruption levels was accessed from the Corruption Perceptions Index (CPI), provided by Transparency International (2018). Food products were classified in different categories according to their SITC codes as they are in the WITS database.

\section{PRESENTATION, INTERPRETATION AND DISCUSSION OF RESULTS}

\section{Panel Unit Root Test}

The variables were tested for stationarity and this was done to avoid spurious regression estimates which results from regressing non-stationary variables. The Im-PesaranShin test for panel unit root results is presented in Tables 1 and 2. 
Table 1: Panel Unit Root Test

\begin{tabular}{lll}
\hline Variable & Probability value & Order of integration \\
\hline MRI $^{\mathbf{x}}$ & $0.0000 * * *$ & $\mathrm{I}(0)$ \\
MRI $^{\mathbf{m}}$ & $0.0000 * * *$ & $\mathrm{I}(0)$ \\
cpi & 0.7775 & Non-stationary \\
fdi & $0.0000 * * *$ & $\mathrm{I}(0)$ \\
gdpc & $0.0060 * * *$ & $\mathrm{I}(0)$ \\
tar & $0.0033 * * *$ & $\mathrm{I}(0)$ \\
infl & $0.0000 * * *$ & $\mathrm{I}(0)$ \\
topen & $0.0592 * *$ & $\mathrm{I}(0)$ \\
\hline$* *$ and *** means that the variables are stationary at $10 \%$ and 1\% significant level; \\
respectively.
\end{tabular}

Trade openness, misreported exports index and misreported exports index, food tariff, inflation, gross domestic product per capita and foreign direct investment inflows as percentage of GDP (fdi) are stationary in levels (integrated of order zero) as indicated in Table 1. Corruption perception index is non-stationary and to be differenced in Table 2.

Table 2:Panel Unit Root test after differencing

\begin{tabular}{lll}
\hline Variable & Probability value & Order of integration \\
\hline D.cpi & 0.0000 & $\mathrm{I}(1)$ \\
\hline$*$ entails stationary at $1 \%$ level of significance and $I(\cdot)$ & shows order of integration
\end{tabular}

After first difference, variable corruption perception index became stationary at the 1 percentage level of significance. Thus, it is integrated of order one.

\section{Multicollinearity}

Table 3: Muticollinearity test

\begin{tabular}{lllllll}
\hline & D.cpi & $f d i$ & gdpc & topen & tar & infl \\
D.cpi & 1.0000 & & & & & \\
fdi & 0.0701 & 1.0000 & & & & \\
gdpc & 0.1225 & -0.1501 & 1.0000 & & & \\
topen & 0.2004 & 0.4507 & 0.2470 & 1.0000 & & \\
tar & -0.0757 & -0.2909 & -0.2689 & -0.3242 & 1.0000 & \\
infl & -0.0086 & 0.0303 & -0.0228 & 0.1196 & 0.1066 & 1.0000 \\
\hline
\end{tabular}

From Table 3, all the pair-wise correlations are less than absolute 0.8, meaning that there is no serious problem of multicollinearity. Hence, plainly, explanatory variables do not move together in systematic ways meaning that there is no exact linear relationship among the independent variables, thus their individual effects on the explained variable can be isolated (Gujarati, 2004). 


\section{Hausman Test}

Table 4: Hausman (1978) specification test for $\mathrm{MRI}^{\mathrm{X}}$

\begin{tabular}{lr}
\hline & Coef. \\
\hline Chi-square test value & 14.62 \\
P-value & 0.0121 \\
\hline
\end{tabular}

The $\chi^{2}$ value for the Hausman test is 14.62 with a corresponding p-value of 0.0121 meaning reject the null hypothesis that the difference in the coefficients is not systematic at $5 \%$ significance level, implying that the FEM is appropriate and is to be preferred to the REM. From the test between fixed effects model and pooled OLS model a p-value of 0.0090 (shown in appendix) show that the FEM is preferred. The heteroscedasticity test shows a pvalue of 0.0000 which strongly rejects the null hypothesis at $1 \%$ level of significance and conclude that there is a presence of heteroscedasticity. The Wooldridge test for autocorrelation detected the presence of autocorrelation which is shown by a p-value of 0 . 0554. Finally, the errors exhibit cross-sectional correlation which is shown by p-value of 0.0023. The study, therefore, estimated the model for FEM with Feasible Generalized Least Squares (FGLS).

Table 5: Hausman specification test for $\mathrm{MRI}^{\mathrm{m}}$

\begin{tabular}{lc}
\hline & Coef. \\
\hline Chi-square test value & 13.63 \\
P-value & 0.0181 \\
\hline
\end{tabular}

The $\chi^{2}$ value for the Hausman test is 13.63 with a corresponding p-value of 0.0181 meaning reject the null hypothesis that the difference in the coefficients is not systematic at 5\% significance level, implying that the FEM is appropriate and is to be preferred to the REM. From the test between fixed effects model and pooled OLS model a p-value of 0.0143 (shown in appendix) show that the FEM is preferred. The heteroscedasticity test shows a pvalue of 0.0852 which strongly rejects the null hypothesis and concludes that there is presence of heteroscedasticity. The Wooldridge test for autocorrelation detected the absence of autocorrelation which is shown by a p-value of 0.2770 . Finally, the errors exhibit no crosssectional correlation which is shown by p-value of 0.1055 . The study, therefore, estimated the model for FEM with Feasible Generalized Least Squares (FGLS). 


\section{Results Discussion}

The results of the factors that causes misreporting of trade for Zimbabwe bilateral trade are presented below first using exports misreported model, followed by the imports misreporting model.

\begin{tabular}{lllll}
\hline Variables & Coefficient & Std. error & z-statistic & Prob $>|\mathbf{z}|$ \\
\hline D.cpi & 0.0003 & 0.0012 & 0.27 & 0.785 \\
tar & 0.0037 & 0.0012 & 3.13 & $0.002^{* * *}$ \\
topen & -0.0027 & 0.0007 & -3.37 & $0.000^{* * *}$ \\
gdpc & 0.00002 & 0.000006 & 3.67 & $0.000^{* * *}$ \\
infl & 0.00015 & 0.0005 & 0.30 & 0.764 \\
fdi & 0.0031 & 0.0018 & 1.73 & $0.084 *$ \\
cons & 0.3015 & 0.0567 & 5.32 & $0.000^{* * *}$ \\
\hline $\begin{array}{l}\text { Table 6:Results with MRI }{ }^{\mathrm{x}} \text { as a dependent variable } \\
* * * \text { and } * \text { entails stationary at 1\% and 10\% level of significance }\end{array}$ &
\end{tabular}

Table 8 presents results from the conducted regression, with standard errors, $\mathrm{z}$ statistic and the associated p-value. In the regression exports misreporting index was regressed on the six variables. Conforming to Olsevskaja (2013), the coefficient of foreign direct investment inflows as a percentage of GDP was found to be statistically significant at $1 \%$ significance level with an expected positive coefficient. FDIs were found to be positively correlated with export misreporting. FDIs have genuine effect on exports misreporting according to the results of the regression. This fact confirms our hypotheses and indicates trade mispricing in case of exports. It means that as the FDI to Zimbabwe is increasing exporting misreporting is also increasing. The results of the regression suggests that holding other things constant a $1 \%$ increase in FDI is associated with $0.003 \%$ increase in exports misreporting index.

The results concerning tariff rates provide strong support for the hypothesis that an increase in tariff rate is associated with a significant increase in trade misreporting. The findings in Table 6 shows that a 1\% increase in average food tariff rate of the importing country results in $0.004 \%$ increase in exports misreporting index. The coefficient of tariff of the exporting country is statistically significant at $1 \%$ level of significance and positively influences exports misreporting in the food products which is in line with the theoretical expectation. From the results, tariff is a key determinant of a country's export misreporting. This indicates that a higher tariff shows higher production levels of exports misreporting. The results are consistent to those found by Patnaik et al. (2010) and Olsevskaja (2013).

Contrary to the expected sign in Chapter Three, trade openness also shows up as a significant predictor of export misreporting with a strong negative influence on export misreporting. On the other hand, increased trade openness is associated with a reduction in 
misreporting of exports. The coefficient of trade openness is significant at $1 \%$ level. A one per cent increase in trade openness results in a $0.003 \%$ decline in export misreporting. A larger tradable sector offers lesser opportunities for agents to misreport exports, which is mainly done with the objective of moving capital outside the country. The results are also contrary to empirical literature. The results are similar to those by Tandon and Rao (2017) in the case of imports misinvoicing. This might be derived from the fact that investors find favourable conditions to conduct business in a country which is more open to international markets and consider no need to move their capital outside the country.

In line with the expectation, the results also show that the coefficient of Gross Domestic Product per capita was significant and positively associated with the misreporting of exports. This means that a unit increase in Gross Domestic Product per capita results in approximately 0.00002 increases in exports misreporting index. Thus, the results indicates that real GDP per capita is positively and significantly related to export misreporting, in that an increase in Gross Domestic Product per capita by itself will drive rather than curtail export misreporting if overall governance does not improve. This confirms results of Kar and LeBlanc (2013) that there is a positive relationship associated with the illicit flows through exports misreporting and gross domestic product.

Finally, we can put these magnitudes in context with a simple back-of-the-envelope calculation. For example, what would a 0.060 export misreporting index means? The meaning is that misreporting of exports would be around US\$6.4 for every US\$100 reported. Therefore, an estimated US\$6.4 of taxable revenue is lost due to misreporting of exports (see the computations done at the end of the chapter). This computation is according to Farhad et al. 2018.

Table 7: Results with $\mathrm{MRI}^{\mathrm{m}}$ as a dependent variable

\begin{tabular}{lllll}
\hline Variables & Coefficient & Std. error & z-statistic & Prob $>|\mathbf{z}|$ \\
\hline D.cpi & -0.0024 & 0.0017 & -1.41 & 0.158 \\
tar & 0.0094 & 0.0016 & 5.74 & $0.000^{* * *}$ \\
topen & -0.0003 & 0.0010 & -0.29 & 0.768 \\
gdpc & 0.00002 & 0.000009 & 1.94 & $0.053^{* *}$ \\
infl & -0.0004 & 0.0007 & -0.61 & 0.545 \\
fdi & 0.0030 & 0.00251 & 1.20 & 0.231 \\
cons & 0.1282 & 0.0791 & 1.62 & 0.105 \\
\hline$* * *$ and $* *$ entails stationary at 1\% and 10\% level of significance &
\end{tabular}


From Table 7 regarding import misreporting, the most interesting finding is that the coefficient of average food tariff rate on imports (obtained from the World Trade Organization) is positive and significant. This indicates that a $1 \%$ increase in food imports tariff, increases misreporting index by $0.094 \%$. This means an increase in import duty rates will increase import misreporting. Tariffs have positive effect on imports misreporting, this suggests that imports misreporting is much stronger in case of tariffs than erroneous declaration of the quantity. The sign of the coefficient of tariff is in line with the theoretical expectations. Similar results were also found by Javorcik and Narciso (2008), Olsevskaja (2013) and Farhad et al. (2018).

The study also finds that the coefficient of gross domestic product per capita is positive and statistically significant at $10 \%$ level. This is in line with the study by Kar and LeBlanc (2013) on trade misinvoicing. However, the results should be taken with caution. Bhagwati's seminal article on the determinants of capital flight from developing countries in 1974 suggests that the high level of de facto capital controls present in developing countries incentivizes traders to circumvent these restrictions through trade misinvoicing. Using this logic, the easing of de facto restrictions on capital movements should result in less trade misinvoicing over time since legal channels are now available for shifting capital abroad. The surprising fact, however, is that much of the developing world has gone through substantial capital account liberalization since the 1970s and the problem of trade misinvoicing has only worsened. One explanation for this may be that openness and liberalization alone cannot curtail misreporting if such liberalization is not accompanied by greater regulatory oversight. Rather, openness in the presence of weak governance can be a prescription for more illicit flows.

\section{Average Misreporting Indices}

Following the theoretical framework outlined in chapter three, Table 8 and Table 9 presents the derived average misreporting of exports and imports misreporting, respectively, for each reporting country per categorised period of 2000-2005, 2006-2011 ad 2012-2016. Through construction (following Farhad et al. (2018)), all indices range between zero and one, where values approaching zero represent less misreporting and higher values indicate more misreporting.

Table 8: Average Export Misreporting Index $\left(\mathrm{MRI}^{\mathrm{x}}\right)$ for the Countries

\begin{tabular}{|l|l|l|l|}
\hline & $\mathbf{2 0 0 0 - 2 0 0 5}$ & $\mathbf{2 0 0 6 - 2 0 1 1}$ & $\mathbf{2 0 1 2 - 2 0 1 6}$ \\
\hline Zimbabwe & 0.074 & 0.212 & 0.443 \\
\hline South Africa & 0.329 & 0.232 & 0.141 \\
\hline Mozambique & 0.156 & 0.106 & 0.134 \\
\hline Malawi & 0.213 & 0.266 & 0.238 \\
\hline Zambia & 0.330 & 0.330 & 0.323 \\
\hline Botswana & 0.359 & 0.179 & 0.101 \\
\hline
\end{tabular}

From the Table 8 above Zambia have been the country which recorded high level of food exports misreporting. Over the years Zimbabwe has increased in the pace of food exports misreporting, while South Africa and Botswana have managed to reduce food exports misreporting. Countries which have scored higher misreporting indices may be a reflective of 
a weak state of governance, more restrictive policies, and capacity limits to record and report trade statistics with precision.

Table 9: Average Import Misreporting Index $\left(\mathrm{MRI}^{\mathrm{m}}\right)$ for the Countries

\begin{tabular}{|l|l|l|l|}
\hline & $\mathbf{2 0 0 0 - 2 0 0 5}$ & $\mathbf{2 0 0 6 - 2 0 1 1}$ & $\mathbf{2 0 1 2 - 2 0 1 6}$ \\
\hline Zimbabwe & 0.434 & 0.251 & 0.236 \\
\hline South Africa & 0.294 & 0.199 & 0.272 \\
\hline Mozambique & 0.378 & 0.333 & 0.154 \\
\hline Malawi & 0.207 & 0.319 & 0.193 \\
\hline Zambia & 0.491 & 0.409 & 0.356 \\
\hline Botswana & 0.459 & 0.278 & 0.170 \\
\hline
\end{tabular}

From the Table 9 above Zambia recorded all time food imports misreporting index from 2000 to 2016. Over the years Zimbabwe and Botswana managed to control imports misreporting as the food imports misreporting indices on average decreased over the period of 2000-2016.

To provide a quantitative example as to what the index means in practice, consider the case of Zimbabwe. A score of 0.434 in the food imports misreporting index for a given period indicates that for each US\$100 of reported trade, Zimbabwe misreported its trade value by approximately US\$76.68. This follows directly from the index calculation in equation 3.12 since for reporting US\$100, we get $0.434=\frac{\widetilde{M}_{d}}{\widetilde{M}_{d}+100}$, which, after some simple algebra, produces $\widetilde{M}_{d}=\$ 76.68$. This calculation can also be done for exports misreporting.

\section{Summary of the findings and conclusion}

This study was undertaken to establish the factors which determine misreported trade with special reference to Zimbabwe and trading partners from 2000-2016. The study zeroed on misreporting trade of food products namely live animals, beverages, tobacco, oil-seeds, oil nuts oil kernels, vegetables oils and fats. In this regard, panel data was collected from secondary data sources and used for the study. Two regressions models were estimated. The study used imports and exports misreporting models to answer the research objectives.

In estimating the factors which determine misreporting of trade on food exports for Zimbabwe bilateral trade, GDP per capita, inflation, net foreign direct investment as a percentage of GDP, corruption perception index, weighted average food tariff and trade openness were used as the independent variables in the study. With the coefficients of GDP per capita, net foreign direct investment as a percentage of GDP, trade openness and weighted average food tariff variable were found to be statistically significant whilst the coefficients of inflation and corruption perception index were found to be statistically insignificant. The results showed that export misreporting increased with an increase in GDP per capita, net foreign direct investment as a percentage of GDP and weighted average food tariff.

Factors which determine food imports misreporting were estimated using the same dependent variables as in export misreporting model. GDP per capita and food tariffs were found to be positively related with import misreporting index. This implies that food imports 
misreporting are mainly determined by GDP per capita and food tariffs. Net foreign direct investment, inflation, corruption perception index and trade openness coefficients were found to be statistically insignificant.

An important conclusion that was drawn from the results was GDP per capita, inflation, net foreign direct investment as a percentage of GDP, corruption perception index, weighted average food tariff and trade openness are the factors which determine misreporting of trade for Zimbabwe bilateral trade.

\section{Policy implications and recommendations}

Policy measures to arrest the problem of misreporting of trade can be suggested based on the empirical findings reported in this paper. A suitable and stable macroeconomic environment that eliminates domestic macroeconomic policy errors will ensure that the economic functions, which bring about misreporting trade, are recommended.

With regards to gross domestic product and foreign direct investment inflows increases these two have been noted to have an increased volume of international trade. A comprehensive and dynamic risk management system is the cornerstone to effective Customs control. A range of factors should be taken into account when developing a risk programme. These include: importer and exporter profiles which record historic compliance records and other relevant data on the business in question provide a key indicator to future risks. This should include details of previous irregularities, under-declarations and penalties imposed. High compliant operators should be subject to fewer documentary and physical checks at the frontier and post-importation. Customs can then direct their resources to the higher risk operators where there is a greater likelihood of discovering errors, possible fraud and underpaid revenue. A process of continued review of compliance levels is required to ensure such profiles are up to date.

There is need for the development and use of a valuation database as a risk assessment tool for tariff evasion and avoidance. Use of valuation database as a means to identify potential misreporting and mispricing of goods is noticed. Such databases can be useful tools, particularly for developing countries like the ones which were involved in this study where there are typically high rates of non-compliance, coupled with poor or nonexistent accounts and record-keeping. The best source of data for such databases is prices taken from recent previously accepted Customs declarations. Where a comparison with database prices for the same type of goods suggests the declared value may not be correct, Customs should seek further evidence from the importer or exporter to support the declared value. A suspect price may not be rejected without conducting an enquiry and giving the importer or exporter the opportunity to provide further evidence.

Furthermore, the research found a reduction in export misreporting when trade openness increases. Therefore, Zimbabwe and trading partners needs to further reduce trade barriers and promote international trade by reducing and simplifying procedures and controls. However, the heavily dependence on international trade may be detrimental to fiscal sustainability and economic growth. Zimbabwe exports mainly primary products, which prices are unstable and determined on the international market. For outward-oriented strategy to have much benefit to the country should modify the composition of trade by switching from exports of raw materials and semi-manufactured goods to high valued-added goods. 


\section{REFERENCES}

Aboud, Z.S., (2009): Determinants of Capital Flight in Kenya (1987-2007)/ (Doctoral dissertation, School of Economics, University of Nairobi).

Baltagi, H. B., (2008): Econometric Analysis of Panel Data. Fourth edition. Wiley.

Baum, C.F., (2001): Residual diagnostics for cross-section time series regression models. The Stata Journal, 1(1), 101-104.

Biswas, A.K., (2011): Tariffs and imports misinvoicing under oligopoly. Economics \& Politics, 23(2), 254-270.

Biswas, A.K., (2012); Import tariff led export under-invoicing: A paradox. The Journal of International Trade \& Economic Development, 21(3), 347-360.

Bredenkamp, H and Schadler, S (eds)., (1999): Economic Reforms and Adjustment in Lowincome Countries, Washington, DC: International Monetary Fund.

Buehn, A. and Eichler, S., (2010); Trade Misinvoicing: The Dark Side of World Trade. Journal of the World Economy.

Buehn, A. and Eichler, S., (2011); Trade misinvoicing: The dark side of world trade. The World Economy, 34(8), 1263-1287.

Cameron, A. C. and Trivedi, K. P. (2005): Microeconometrics Methods and Applications. First edition. Cambridge University Press. New York.

Dalu, T., Maposa, V.G., Pabwaungana, S. and Dalu, T., (2012): The impact of tax evasion and avoidance on the economy: a case of Harare, Zimbabwe. African Journal of Economic and Sustainable Development, 1(3), 284-296.

de Boyrie, M.E., Nelson, J.A. and Pak, S.J., (2007): Capital movement through trade misinvoicing: the case of Africa. Journal of Financial Crime, 14(4), 474-489.

Dube, G., (2014): Informal sector taxation: the case of Zimbabwe (Doctoral dissertation, Georgetown University).

Ekananda, M., (2018): Misinvoicing Analysis in ASEAN-China Free Trade Aggrement (ACFTA). European Research Studies Journal, 21(1), 187-205.

Farhad, M., Jetter, M., Siddique, A. and Williams, A., 2018. Misreported Trade. World Bank Publications.

Farzanegan, M.R., (2009): Illegal trade in the Iranian economy: Evidence from a structural model. European Journal of Political Economy, 25(4), 489-507.

Ferrantino, M.J., Liu, X. and Wang, Z., (2012): Evasion behaviors of exporters and importers: Evidence from the US-China trade data discrepancy. Journal of international Economics, 86(1), 141-157.

Ferrantino, M.J., Liu, X. and Wang, Z., (2012): Evasion behaviors of exporters and importers: Evidence from the US-China trade data discrepancy. Journal of international Economics, 86(1), 141-157.

Ferrantino, M.J., Liu, X. and Wang, Z., (2016): Evasion behaviors of exporters and importers: Evidence from the US-China trade data discrepancy. Journal of international Economics, 86(1), 141-157. 
Fisman, R., Moustakerski, P. and Wei, S.J., (2008): Outsourcing tariff evasion: A new explanation for entrepôt trade. The Review of Economics and Statistics, 90(3), 587-592.

Gupta, A.S. and Shah, A., (2012): Determinants of trade misinvoicing. Open Economies Review, 23(5), 891-910.

IMF, (2018): A Guide to Direction of Trade Statistics. International Monetary Fund (IMF).

Javorcik, B.S. and Narciso, G., (2008): Differentiated products and evasion of import tariffs. Journal of International Economics, 76(2), 208-222.

Johnston, J. and DiNardo, J., (1972): Econometric methods (Vol. 2). New York.

Kar, D. and LeBlanc, B., 2013. Illicit Financial Flows from Developing Countries: 20022011, Washington, DC: Global Financial Integrity

Kar, D. and Spanjers, J., (2015): Illicit financial flows from developing countries: 2004-2013. Global Financial Integrity, 1-10.

Kellenberg, D. and Levinson, A., (2016): Misreporting trade: Tariff evasion, corruption, and auditing standards. Technical report, National Bureau of Economic Research.

Kwaramba, M., Mahonye, N. and Mandishara, L., 2016. Capital flight and trade misinvoicing in Zimbabwe. African Development Review, 28(S1), 50-64.

Levin, J. and Widell, L., 2007. Tax evasion in Kenya and Tanzania: Evidence from missing imports. Department of Business, Economics, Statistics, and Informatics, University of Örebro.

Lipsey, R.G., (2008): Positive economics. The New Palgrave Dictionary of Economics: Volume 1-8, 5037-5040.

Moeva, Z.S.D., (2013): Determinants of Capital Flight in Kenya (1987-2007, University Of Nairobi. Available at SSRN: http://erepository.uonbi.ac.ke/

Murphy, M., (2011): El otro hueco comercial: corruption and the misreporting of exports in Latin American economies (Doctoral dissertation, Georgetown University).

Nitsch, V., (2009): Die another day: Duration in German import trade. Review of World Economics, 145(1), 133-154.

Nitsch, V., (2017): Trade Misinvoiving in Developing Countries. CGD Policy Paper, 103.

Ogalo, V., (2010): Informal cross-border trade in EAC: Implications for Regional Integration and Development. CUTS African Resource Centre, Nairobi.

Olsevskaja, D., (2013): Trade Mispricing and Misreporting: A Study of China's Foreign Trade 1998-2009 (Master's thesis).

Olsevskaja, D., (2013): Trade Mispricing and Misreporting: A study of China's Foreign Trade 1998-2009, University Of Oslo: Reprosentralen.

Olsevskaja, D., (2013): Trade Mispricing and Misreporting: A Study of China's Foreign Trade 1998-2009 (Master's thesis).

Panayi, C.H., (2015): Advanced issues in international and European tax law. Bloomsbury Publishing.

Patnaik, I., Gupta, A. and Shah, A., (2010): Determinants of trade misinvoicing. New Delhi: Publications Unit, National Institute of Public Finance and Policy. 
Patnaik, I., Gupta, A.S. and Shah, A., (2012): Determinants of trade misinvoicing. Open Economies Review, 23(5), 891-910.

Pedroni, P. (2001): Fully Modified OLS for Heterogeneous Cointegrated Panels. Indiana: Emerald Group Publishing Limited.

Pesaran, M. H. (2004). General Diagnostic Tests for Cross Section Dependence in Panels. htt://ssm.com/abstract=572504.

Qureshi, T.A. and Mahmood, Z., (2015): The Size of Trade Misinvoicing in Pakistan. Lincoln University

Sarafidis, V. and Wansbeek, T., (2012): Cross-sectional dependence in panel data analysis. Econometric Reviews, 31(5), 483-531.

Silverstone, H., Sheetz, M., Pedneault, S. and Rudewicz, F., (2004): Forensic accounting and fraud investigation for non-experts (Vol. 2). Hoboken, NJ: Wiley.

Slemrod, J., (2018): Tax compliance and enforcement (No. w24799). National Bureau of Economic Research.

Squalli, J. and Wilson, K., (2006): A new approach to measuring trade openness. Economic \& Policy Research Unit Working Paper, (06-07).

Suryanto, T., (2016): Audit Delay and Its Implication for Fraudulent Financial Reporting: A Study of Companies Listed in the Indonesian Stock Exchange. European Research Studies Journal, 19(1), 18-31

Tandon, S. and Rao, K., (2017): Trade misinvoicing: What can we measure? (No. 17/200). National Bureau of Economic Research.

Thompson, T. and Shah, A., (2005): Transparency international's corruption perceptions index: Whose perceptions are they anyway. Retrieved May, 14, p.2013.

Wood, E. and Moll, T., (1994): Capital flight from South Africa: is underinvoicing exaggerated? South African Journal of Economics, 62(1), 17-28.

World Bank. (2018): World Development Indicators. Washington, D.C.

Yalta, A.Y. and Demir, I., (2010): The extent of trade mis-invoicing in Turkey: did post-1990 policies matter? Journal of Economic Cooperation and Development, 31(3), 41-66. 